\title{
Familial diabetes mellitus with variable B cell reserve; analysis of a pedigree
}

\author{
H.J. Bodansky and W.F. Kelly \\ Professorial Medical Unit, The General Infïrmary, Leeds, General Hospital, Middlesborough, UK
}

\begin{abstract}
Summary. Some patients do not fall neatly into the categories of Type 1 (insulin-dependent), Type 2 (non-insulin-dependent) or maturity onset diabetes of young people diabetes. The pedigree and characteristics of the family reported here illustrate this problem. Nine cases of diabetes are known in 4 out of 5 generations, with onset between 17-70 years. Treatment was with insulin in 5 (onset 17-29 years), tablets in 3 (onset 32-70 years), and in one diabetes occurred before the insulin era. Plasma C-peptide was $0.04-0.52 \mathrm{nmol} / 1$ (fasting) and $0.35-1.33 \mathrm{nmol} / 1$ (peak stimulation with glucagon). HLA typing, available in 7 diabetic patients showed DR2 or DR7 in all, DR4 in 2 and DR3 in none. Pancreatic islet cell antibodies were absent at diagnosis in the most recently diag-
\end{abstract}

nosed patient. Diabetic complications remain absent in two insulin-treated patients (duration 28 and 24 years), but have occurred extensively in the remainder. The form of diabetes in this family is therefore characterised by (a) strong family history (possible autosomal dominant with variable penetrance), (b) widely variable age of onset, (c) a variable degree of B cell reserve (d) no association with HLA DR3/4 and the presence of DR2 or DR7 and (e) no protection from complications.

Key words: Diabetes, classification, insulin-dependent, noninsulin-dependent, genetics, pancreas, insulin, HLA.
The classification of diabetes remains controversial [1], but many clinicians currently use that proposed by the National Diabetes Data Group [2]. Most patients will fit the categories of Type 1 (insulin-dependent) or Type 2 (non-insulin-dependent) diabetes. Each of these has distinct clinical, immunological, metabolic and genetic characteristics $[3,4]$. A small group of patients may fit with the category of Mason-type or maturityonset diabetes of young people (MODY diabetes) [5, 6]. However, some patients do not fit this rigid classification and it may be helpful to describe variants or sub-types which will expand and refine the categorisation of these subjects.

The pedigree and characteristics of the family described here illustrate this problem.

\section{Subjects and methods}

The proband, Mrs. ET (subject IV.5), was diagnosed diabetic at the age of 23 and was ascertained during a study of genetic factors influencing diabetic complications. She reported a strong family history of diabetes. As she had an unusual HLA type for a patient with Type 1 diabetes, her family was investigated further. She is a member of a family, most of whom reside in Redcar, Cleveland, UK and sur- rounding areas. All available diabetic and non-diabetic members of the family were asked about their medical histories and the presence of any diabetic complications. The latter information was obtained either from current examination in diabetic clinics, information from the General Practitioner or from a questionnaire sent to the patient. Wherever possible, blood was taken for HLA typing and C-peptide estimation. HLA typing was performed by standard techniques. Plasma C-peptide levels were estimated by standard kit methods [7] both fasting and after glucagon $1 \mathrm{mg}$ i.v. [normal adult values (range): fasting $=0.36(0.26-0.63)$ stimulated $1.28(0.91-1.88) \mathrm{nmol}$ 1]. During study of the family, subject V.10, a daughter of the proband, developed diabetes. Her sera and her mother's were tested for the presence of islet cell antibodies (ICA) using double antibody immunofluorescent techniques [8].

\section{Results}

Nine family members in four out of five generations had diabetes (Fig. 1), the clinical details of whom are given in Table 1. The earliest known diabetic patient was JS (I.1) who was reported by all his relatives to have developed diabetes and died shortly afterwards at age 38. Subject II.1 was not reported to have had any siblings and was not known to be diabetic. However, three out of 7 siblings in generation III were known to 


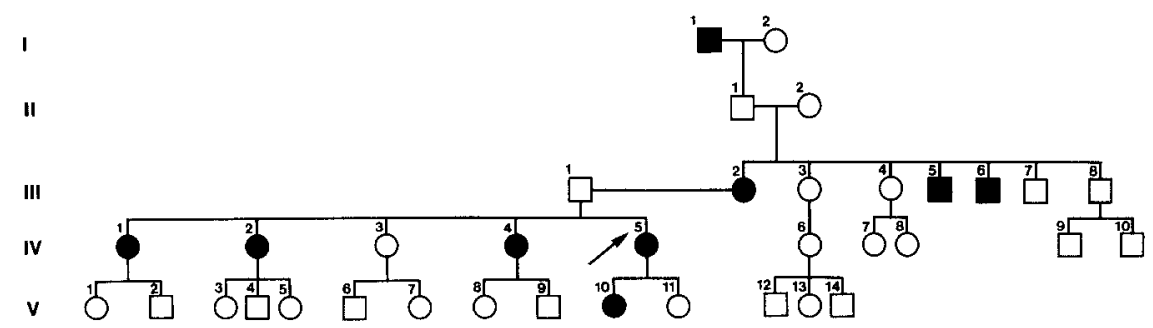

Fig.1. Family pedigree $\square$ Male without diabetes; $\bigcirc$ female without diabetes. $\square$ male with diabetes; cates the proband, Ms. ET, Case IV.5

Table 1. Clinical details of the diabetic members of the S. family

\begin{tabular}{|c|c|c|c|c|c|c|}
\hline Subject & $\begin{array}{l}\text { Date } \\
\text { of birth }\end{array}$ & $\begin{array}{l}\text { Age at } \\
\text { diagnosis } \\
\text { (years) }\end{array}$ & Treatment & $\begin{array}{l}\text { HLA type and } \\
\text { ICA status }\end{array}$ & $\begin{array}{l}\text { Plasma C-peptide } \\
\text { fasting; peak } \\
\text { (nmol/1) }\end{array}$ & Outcome \\
\hline I.1 JS & $\begin{array}{l}\text { Estimate } \\
1860\end{array}$ & 38 & Nil & NA & NA & Died soon after diagnosis \\
\hline III.2 GR & 1906 & 70 & Tablets & $\begin{array}{l}\text { A2, B12, CW6, } \\
\text { DR7, A29, BW44, } \\
\text { CW-DR7 }\end{array}$ & NA & $\begin{array}{l}\text { Died aged } 73 \text {, myocardial in- } \\
\text { farction }\end{array}$ \\
\hline III.6 HS & 1919 & 40 & Tablets & $\begin{array}{l}\text { A2, W19, B7, B44, } \\
\text { DR2, DR7 }\end{array}$ & $0.40 ; 1.33$ & $\begin{array}{l}\text { Peripheral vascular disease, } \\
\text { neuropathy, ischaemic heart } \\
\text { disease }\end{array}$ \\
\hline IV.2 DL & 1931 & 32 & Tablets & $\begin{array}{l}\text { A2, - B13, B15, } \\
\text { DR4, DR7 }\end{array}$ & $0.52 ; 0.86$ & $\begin{array}{l}\text { Retinopathy, ischaemic heart } \\
\text { disease }\end{array}$ \\
\hline IV.4 MM & 1939 & 23 & $\begin{array}{l}\text { Insulin } \\
\text { started during gestational } \\
\text { diabetes }\end{array}$ & $\begin{array}{l}\text { A2, W19, BW44, } \\
\text { B15, DR4, DR7 }\end{array}$ & $0.4 ; 1.07$ & No complications \\
\hline IV.5 ET & 1943 & 23 & $\begin{array}{l}\text { Insulin } \\
\text { started at } 2 \text { nd period of } \\
\text { gestational diabetes }\end{array}$ & $\begin{array}{l}\text { A1, B7, CW7, DR2, } \\
\text { A2, B13, CW6, } \\
\text { DR7, ICA neg }\end{array}$ & 0.04 (random) & Proliferative retinopathy \\
\hline V.10 JT & 1967 & 17 & $\begin{array}{l}\text { Insulin } \\
\text { started at diagnosis }\end{array}$ & $\begin{array}{l}\text { A2, A9, B7, B35, } \\
\text { DR2, DR7, ICA } \\
\text { neg }\end{array}$ & $0.18 ; 0.35$ & No complications \\
\hline
\end{tabular}

No family member is known to have had diabetic ketoacidosis except III.5 when terminally ill with rectal carcinoma and renal impairment. NA - Not available. HLA type either phenotype or genotype

have diabetes, four out of five siblings in generation IV, while only one subject has become diabetic so far in generation V. Excluding subject I.1 because the onset of diabetes was before treatment became available, five have been insulin-treated and three treated with oral agents. Plasma C-peptide values are available in six diabetic patients and all are insulinopaenic, with those on insulin tending to have lower values than those on oral agents. The variation in age at diagnosis was wide (17-70 years), and insulin was given to those with a younger age at onset. No diabetic family member was obese.

HLA typing was available in seven subjects. HLADR4 was present in only two (siblings in genera- tion IV), while DR3 was not present in those tested. All possessed DR2 or DR7. Sera were examined in the only recently diagnosed diabetic patient (V.10) and her mother (IV.5) and ICA were absent. Morbidity and mortality were variable. Subject I.1 died shortly after diagnosis due to lack of treatment. Two others have died (III.2 and III.5) of a myocardial infarction and rectal carcinoma, respectively. Two (IV.1 and IV.4), both insulin-treated, have remained free of diabetic complications so far, despite long duration of disease (28 and 24 years). However, the others have developed various diabetic complications (Table 1). Patient IV.5 has developed severe proliferative retinopathy and has had laser photocoagulation. 


\section{Discussion}

Many patients do not fit with the currently used categories of Type 1, Type 2 or MODY diabetes. Exploring the heterogeneity of diabetes may lead to a greater understanding of diabetic pathogenesis in its various forms.

The family described here shows a vertical transmission of diabetes from generations I to $\mathrm{V}$, although subject II.1 was not known to be diabetic. This would be compatible with an autosomal dominant mode of inheritance with some variable penetrance. This is not typical of Type 1 diabetes and most closely fits with MODY, where it may be seen in some families [5]. The age at onset of diabetes was widely variable, and apart from subject III.2, all developed diabetes before age 40 years, making Type 2 diabetes unlikely.

The available C-peptide values varied from normal to very low. Those with the lowest values tended to be insulin treated and those with moderately low values were treated with oral hypoglycaemic agents. Two subjects, III.6 and IV.4, on tablets and insulin, respectively, had C-peptide values within the normal range. This variation in $B$ cell reserve spans the range between that seen in Type 1 diabetes and that seen in the thin noninsulin-treated patient who may respond to sulphonylureas [9]; most cases of MODY tend to have relative hypoinsulinaemia [10].

Whilst Type 1 diabetes is associated with HLADR3 and DR4, Type 2 diabetes and MODY probably have no HLA association [11-13]. No subject in this family who was HLA-typed possessed DR3 and only two have DR4. DR2 and DR7 which are unusual in, and may protect against, Type 1 diabetes, were particularly prevalent (although common in the general Caucasoid population [11]). However, one cannot draw strong conclusions from HLA typing in related members of one family.

Islet cell antibodies are found in most cases of recently diagnosed Type 1 diabetes [14]; only one patient (V.10) was seen at the time of diagnosis and she was ICA-negative.

Patients with MODY are said to be relatively spared from diabetic complications [5]. The complications outcome of the diabetic patients in this family was variable. Despite long duration of insulin-treated diabetes, two patients are free of complications, while the remainder have developed vascular disease.

One could argue that this family is not unique and that there is merely an unusual clustering of patients with either Type 1 or Type 2 diabetes. However, if one considers that the form of diabetes present here breeds true, then the features of the disease in this family may suggest a separate entity characterised by a strong familial tendency, a variable age of onset, relative insulinopaenia, no association with HLA-DR3/4 and a lack of protection from diabetic complications.

Acknowledgements. We thank the physicians concerned for allowing us to study their patients, Dr. R. B. Tattersall for advice, Dr. K. Gelsthorpe for HLA typing. Dr. David Price for C-peptide estimations, Dr. G.F.Bottazzo for ICA testing and Ms. M.E.Smith for secretarial assistance.

\section{References}

1. Keen $\mathrm{H}$ (1986) What's in a name? IDDM/NIDDM, Type 1/Type 2. Diabetic Med 3: 11-12

2. National Diabetes Data Group (1979) Classification and diagnosis of diabetes mellitus and other categories of glucose intolerance. Diabetes 28: 1039-1057

3. Cudworth AG (1978) Type 1 diabetes mellitus. Diabetologia 14: 281-291

4. Cudworth AG (1979) Type 2 (insulin-dependent) diabetes - fibres and flushers. Diabetologia 17: 67-69

5. Tattersall RB (1974) Mild familial diabetes with dominant inheritance. Q J Med 43NS: 339-357

6. Tattersall RB, Fajans SS (1975) A difference between the inheritance of classical juvenile-onset and maturity-onset type diabetes of young people. Diabetes 24: 44-53

7. Heding LG (1975) Radioimmunological determination of human C-peptide in serum. Diabetologia 11: $541-548$

8. Bottazzo GF, Dean BM, Gorsuch AN, Cudworth AG, Doniach D (1980) Complement fixing islet cell antibodies in Type 1 diabetes: possible monitors of active beta-cell damage. Lancet 1 : 668-672

9. Bodansky HJ, Medbak S, Cudworth AG, Rees LS, De Silva RS (1982) Long term improvement in insulin response with gliclazide treatment. Diabete Metab 8: 319-322

10. Barbosa J, Ramsay R, Goetz FC (1978) Plasma glucose, insulin, glucagon and growth hormone in kindreds with maturity-onset type of hyperglycaemia in young people. Ann Int Med 88: 595-601

11. Wolf E, Spencer KM, Cudworth AG (1983) The genetic susceptibility to Type 1 (insulin-dependent) diabetes: analysis of the HLA-DR association. Diabetologia 24: 224-230

12. Rotter JI, Rimoin DL (1979) Diabetes mellitus: the search for genetic markers. Diabetes Care 2: 215-226

13. Barbosa J, King R, Goetz FC, Noreen H, Yunis EJ (1978) HLA in maturity-onset type of hyperglycaemia in the young. Arch Intern Med 138: 90-93

14. Bottazzo GF, Doniach D, Pouplard A (1975) Humoral autoimmunity in diabetes mellitus. Acta Endocrinol [Suppl] 205: 55-64

Received: 15 April 1987

and in revised form: 7 July 1987

Dr. H.J. Bodansky

Professorial Medical Unit

G Floor, Martin Wing

The General Infirmary

Leeds LS1 3EX

UK 